\title{
Implementation of Al-Qur'an Reading Learning Tartili Method in MAS Sinar Serdang Perbaungan
}

\author{
Tira Rahayu ${ }^{1}$, Haidar Daulay ${ }^{2}$, Zulheddi $^{3}$ \\ ${ }^{1}$ Master Students at State Islamic University of North Sumatra \\ ${ }^{2,3}$ Lecrturers at State Islamic University of North Sumatra
}

\section{Abstract}

This research aims to implement learning to read and write alquran's tartili method in MAS Sinar Serdang Perbaungan as well as to improve student achievement in reading the Qur'an from those who are unable to read to be able to read well, correctly and fluently in tartil. From those who do not know the letters to know the letters of Tajweed and the Qur'anic punctuation properly. This program is carried out after midday prayers in congregation. To determine students' ability to read and write letters of the Qur'an, observations, interviews and documentation were carried out in the implementation, planning and evaluation of students in reading and writing the Qur'an in a tartili manner. In order to know the students' abilities in reading and writing, the teacher tests students with tests one by one. The research method used is the method of data reduction, data presentation, and drawing conclusions. To check the validity of the data, it is carried out perseverance of observation, tringuation and discussion of colleagues so that the data is more accurate. As well as field testing in class until the final test by writing.The results of this research find out how many students are able and unable to read and write. And creating students become clerics and clerics to be useful in the community environment.
Keywords

implementation, read write Al-Qur'an, tartili method

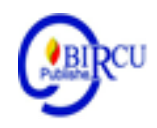

\section{Introduction}

Education is an important factor in realizing intelligent and noble people. With the existence of intelligent and noble people, it is hoped that it will facilitate the achievement of the ideals of the Indonesian nation and state, namely independence, unity, sovereignty, justice and prosperity. According to Shah in Chandra (2009: 33). Education is an effort to foster and develop human personality both in the spiritual or physical parts.

Formal education has advantages compared to non-formal education (education in the family environment). First, formal education in schools has a broader scope of educational content, not only pleasing with moral development, but also science and skills. Secondly, education in schools can provide higher, broader, and deeper knowledge. Third, because it has a formal or written design or curriculum. Education in schools is carried out in a planned, systematic and more conscious manner.

As stated in Law No.20 of 2003 Education is a basic and planned effort to create an atmosphere of learning and learning process so that students actively develop their potential to have spiritual spiritual strength, self-control, personality, intelligence, noble character, and skills, required by himself, the community, and the State (Hariyanto, 2012: 11 February 2020).

Religious education is an integral part of the national education system (Article 12 of the National Education System Law) has a major contribution in the inculcation of spiritual moral values and the diversity behavior of students. Islamic religious education is a conscious 
and planned effort in preparing students to recognize, understand, appreciate, to believe, to be pious and to have good deeds in practicing Islamic teachings from the main sources of the Holy Qur'an and hadith, but to guide, teach, practice, and use of experience.

Islamic Education includes aspects: Al Qur'an and Hadith, Aqeedah, Morals, Fiqh and Date and Islamic Civilization. The position of reading and reading capability of the Qur'an is integrated and independent. Integrated nature means the ability to read and write the Qur'an as a basis or source for studying the subjects of Aqeedah, Morals, Fiqh, Date and Islamic Civilization. While the independent nature means that the ability to read Al Qur'an is the core (core) which is studied separately in the competency standard.

Al-Qur'an is kalamullah revealed to the Prophet Muhammad, as an extraordinary miracle beyond the limits of human ability. One proof of the Qur'an is not human work is the preservation of lafadz and its meaning. Surah, verses and even letters will not change. Allah SWT. which maintains the authenticity of the Qur'an. Unlike the previous holy books, this can happen first and foremost because there is a guarantee from Allah Almighty: "Verily, I am the one who sent down az-Zikr (Al-Qur'an) and in fact We really maintain it -QS Hijr 15: 9. (Budianti, 2020)

Al-Qur'an is the source of all sources of knowledge that creates goodness and prosperity for all mankind in the world. The Qur'an is also the most important means of honoring God both in reading, studying, teaching and listening (Srijatun, Vol. 11, No. 1, 2017: 25).

Reading the Qur'an with the Tartili method according to language means clear and orderly while according to the term is reading the Qur'an slowly and calmly accompanied by tajwid, waqof and makhorijul letters that are in accordance with the Qur'an properly and right. Al-Qur'an is a guide to the life of Muslims that must be well inherited by all Muslims so that their lives will be safe in the world and the hereafter, so learning to read the Qur'an must be done as hard as possible so that students as the next generation of Muslims can master Al- Qur'an well and truly.

Learning about reading and writing the Qur'an using the tartili method is one of the important elements in the PAI subjects in the high school / MA education unit. This has been seen in the 2004 curriculum of PAI subjects that place the competence in reading the Qur'an as one of the basic competencies that students must master. Explanation, Basic competence is reflected in the following indicators, namely so that students are able to: 1) read fluently, 2) explain the application of the science of recitation, and 3) conclude the contents of the Qur'an. However, with such a broad curriculum content that covers all aspects of Islamic religion and with a limited number of hours of study, the basic competence of Reading the Qur'an is difficult to achieve. Therefore, this phenomenon is partly understood by the ability to read and write the Qur'an rather as a technical skill that is not directly related to the substance of religious values.

For this reason, the researchers conducted a deeper study of the Implementation of the Holy Qur'an Read and Write Method for improving the ability of students to read and write well according to the ulumut recitation method. the existence of the Read and Al-Qur'an government program (BTQ) that was socialized through the Serdang Bedagai Ministry of Religion to schools in Serdang Bedagai Regency in 2019 to be implemented and the Ali Sera Sinar Serdang Perbaungan Madrasah School has implemented it in their schools, so researchers are interested to conduct research on implementing this program to be developed later. 


\section{Theoretical Review}

Learning is a concept of two dimensions of activities (learning and teaching) that must be planned and actualized, and directed towards the achievement of objectives and mastery of a number of competencies and indicators as a picture of learning outcomes (Majid, 2013: 5). In the implementation of learning required appropriate learning strategies in order to achieve learning objectives. Learning strategy is a system that is interrelated, among others: objectives, material, methods, evaluation. These components interact with each other in the learning process to achieve the expected goals.

Learning is conditioned to be able to encourage overall creativity, make students active, achieve learning goals effectively and take place in pleasant conditions. Therefore every teacher must believe that: (Munandar, 2011: 207)

1. Learning is very important and very fun.

2. Children should be valued and loved as a unique person.

3. Children should be active students.

4. Children need to feel comfortable in class, and be stimulated to always learn.

5. The teacher is a resource facilitator (facilitator, mediator).

6. The teacher must be competent, but not necessarily perfect.

7. Children need to feel free to discuss problems openly both with the teacher and with peers.

8. Cooperation is better than competition, although in the end they have to take personal responsibility.

9. Learning experiences (learning experience) should be close and come from experiences gained from the real world (real world).

Planning means compiling steps to solve a problem or carry out a work directed at achieving certain goals. In this case the planning includes a series of activities to determine the general goals (Goal) and special goals (objectivists) of an organization or educational provider, based on the support of complete information. After the goals are determined the planning is related to the preparation of a complete pattern, sequence, and activity process. After the goals are set, planning is related to the preparation of patterns, sequences, and the process of activities to be carried out to achieve these objectives. In short, the effectiveness of planning related to the preparation of planning activities to achieve goals, can be measured by the full cooperation of the formulation of planning, madrasa work programs, and efforts to implement the work program in achieving goals (Hadari, 2012: 16).

Implementation carried out in the implementation of reading and writing al-quran's tartili method is this stage takes place interaction between teacher and students, students and students, group students or students individually. The range of this interaction lies between the two extreme poles, namely an activity that is centered on the teacher and a studentcentered activity (Moedjiono (ed), 2012: 39) The process of implementing teaching and learning activities in reading the Qur'an is carried out by the steps:

1. The preliminary words from the teacher to calm students down, publish everything in class, attract students' interest and attention to the lesson and its importance and advantages are good at reading the Qur'an both for themselves and for the Muslim community in general.

2. Start the lesson by reading basmallah together aloud and keeping in mind, may Allah bless you and His mercy, taufiq and His guidance in your learning.

3. Teachers hold apperception and pretest. Apresepsi is asking students about the subject matter of past lessons to refresh their memories and relate them to today's lesson. 
While the pretest is a test given before the lesson begins and aims to find out to what extent the students' mastery of the teaching material to be taught.

4. The most basic and most important basic things taught by the teacher are that students need to know and really know about Surah At-Thinn, Al-Falaq for the first time they must be taught how to pronounce them correctly and fluently verse by verse until completion, by using methods that are appropriate and systematic so that it attracts children and is liked by them, not to complicate them.

5. The teacher reads about and clearly, then is followed by students together. The wrong readings are immediately corrected by the teacher. What needs to be reminded to students is that they should not forget each verse. Students are also trained to write the verses of Surah at Thinn, Al-Falaq in each student's notebook.

6. Teaching the Qur'an requires several repetitions until students can read fluently.

7. The reading exercises of the Qur'an are first jointly led by the teacher, then led by clever students one by one, followed by other students together. Until finally all students read one by one in front of their teacher (individual or private stage) and at that time the teacher also held an assessment of student reading.

In closing, give brief advice and end with saying hamdalah.

The meaning of evaluation as a means of evaluating the achievement of objectives in teaching, evaluation must be carried out continuously. Evaluation is more than just determining the success rate of learning. The most important thing is as a basis for feedback (feedback) of the teaching and learning process carried out. Therefore the teacher's ability to compile tools and conduct evaluations is the ability to be part of the ability to organize the overall teaching and learning process. Evaluation can be divided into two types, namely: Evaluation using standardized tests and Evaluation using non-standardized tests (made by teachers).

Reading and writing are the most valuable commands given to humans, because reading and writing are the paths that bring humans to the perfect degree of humanity (Shihab, Vol. XV: 170). Through ink, kalam and writing, ignorance and ignorance can be removed. The verse also contains a command that shows the obligation to Muslims to explore written science, because only then can they make themselves free from ignorance (Muhaimin, 1993: 253).

The ability to read and write the Qur'an is the most important material and is very basic in Islamic education. Students' ignorance of the Al-Qur'an Read and Write competence will affect their enthusiasm to learn things that are a translation of the content of the Qur'an. The process of achieving this competency is really not as easy as one might imagine. In general there are two influencing factors, namely internal and external influences. Students who have the skills can learn to read and write the Qur'an quickly, while students who do not have the skills will be slow and need special guidance on an ongoing basis.

Learning to Read the Qur'an in the MAS aims to provide basic abilities to students in reading, writing, familiarizing, and liking the Qur'an as well as instilling understanding, understanding, and appreciation of the contents of the verses of the Qur'an to encourage, foster, and guide the morals and behavior of students to be guided in accordance with the contents of the verses of the Qur'an. In addition, learning to read and write the Qur'an is directed to improve the ability of students in terms of reading the Qur'an fluently bi al-tartil, understanding the contents of the verses of the Qur'an, and being able to write it with good writing and true (Department of Education and Culture, 2007: 3).

To be able to read well, it must be accompanied by the rules of reading the Qur'an, namely Tajweed. Tajweed is improving the reading of the Qur'an in the form of removing 
letters from their place by giving the properties they have, both original and later ones (Syarifuddin, 2008: 91).

\subsection{Various Kinds of Learning Method in Reading and Writing Al-Qur'an}

The following learning methods of reading and writing Al-Qur'an related to the method of tartil in reading writing Al-Qur'an include:

\section{a. Baghdadhiyah Method}

The Baghdadhiyah method is a structured method (tarkibiyah), meaning that a method is arranged sequentially and is a repeat process or we are more familiar with the method of alif, ba ', ta'. (Animous, 1414) In the author's view this method is the oldest method to emerge and the first method to develop in Indonesia.

1). How to teach the Baghdadhiyah Method:

a) Initially taught the names of letters hijaiyah according to the rules of Baghdadhiyah rules, which starts from the letters alif, ba ', ta', and until yes'.

b) Then the punctuation marks (harakat) are taught as well as the sound of the reading. In this case the child is guided reading slowly and decomposed/ spelled, such as alif fathah a, alif kasrah i, alif dhammah $\mathrm{u}$, and so on.

c) After the children learn the hijaiyah letters in these ways, then they are taught al-Qur'an juz'amma (the 30th Juz from the order of juz in the Qur'an) (Budiayanto, 1995).

2).Strengths

a) Students will be easy to learn because before being given material already memorized hijaiyah letters, smooth students will quickly proceed to the next material because they are not waiting for others, students are introduced to the name of hijaiyah letters since the beginning of the lesson (Animous, 1414).

3) Weaknesses

a). As for the drawbacks of this method according to the author, it takes a long time because they have to memorize hijaiyah letters first and must be spelled so that students feel bored and many do not finish until they can read the Qur'an.

\section{b. Qiro'ati Method}

The Qiro'ati method is the teaching of reading the Koran by directly practicing tartil reading in accordance with the qa'idah of recitation, teaching volumes 1 and 2 should be individually while teaching volumes 3 to 6 should be classically, but each student is given the opportunity to read ( Zarkasi, 1990).

In the first volume the letters are read directly without spelling quickly and do not elongate the sound, in volume two introduced the name harakat, Arabic numerals and reading mad thabi'i. Volume three is the deepening of volume one and volume two, volume four is introduced to nun sukun, tanwin, mad compulsory and mad jaiz, nun and bermasydid, wawu which are not read. Volume five is taught how to waqof, mafatih al suwar and deepening the previous volume. In volume six it is taught how to read izhar halqi and read al-Qur'an at juz one (Zakarsi, 1990).

The Qiro'ati method was compiled by Ustadz H. Dahlan Salim Zarkasy in 1986 to coincide on July 1. HM Nur Shodiq Ahrom (as a composer in his book "Qira 'ati Qaeda System" Ngembul, Kalipare), this method is reading the Qur'an which directly includes and practices tartil reading in accordance with the qa'idah of the science of tajwid education and teaching systems. This Qira'ati method through a student-centered education system and grade / volume are not determined by the month / year and not classically, but individually (individually). 


\section{c. An-Nahdhiyah Method}

The An-Nahdhiyah method is one of the methods of reading the Qur'an that appears in the Tulung Agung area, Timur Timur. Al-Qur'an study material is not much different from the Qiro'ati and Iqra methods. And keep in mind that this study method emphasizes more on the appropriateness and regularity of the reading with the beats or rather the learning of the Koran in this method places more emphasis on the "knock" code in implementation (Ma'mun, Vol. 4, No. March 1, 2018: 57-59).

The core learning of the An-Nahdhiyah method: In the first volume students are introduced letters that have not been strung together as well as the introduction of fathah, kasrah and dhammah punctuation. The second volume teaches a series of letters, reading mad thabi'i, reading signs, harakat tanwin, introducing Arabic numerals. The third volume was translated, ta 'marbuthah, letters with breadfruit punctuation, alif Fariqah, ikhfak, hamzah washal. The fourth volume is translated izhar qomariah reading, izhar syafawi reading, izhar halqiyah reading, and mad reading is obligatory. The fifth volume is taught lien reading, tasydid sign, ghunnah recitation, idhgam bighunnah, idhgam if ghunnah, and iqlab, how to read the recitation of the path, and recitation of ikhfa 'syafawi. At the end of volumes 1-5 given a daily prayer material. The sixth volume is taught idhgam syamsiyah, qolqolah, mad ladzim kilmi musaqqol / mukhaffaf, mad aridly, mad iwadh, mad prevalent harfi, waqof signs, and choice letters (Ma'arif NU, 1992).

\section{d. Iqra Method}

'The Iqra Method 'is a method of reading the Qur'an which emphasizes direct reading practice. The iqra guide book 'consists of 6 volumes starting from a simple brief, step by step to the perfect level (Human, 2000).

The study of reading al-Qur'an with the Iqra method has been used as a project by the Indonesian Ministry of Religion as an effort to develop an interest in reading the Holy Qur'an. However, it must be recognized that each method has its own advantages and disadvantages. Therefore there needs to be a convergence effort by modifying a number of methods to get interesting, fun, and effective learning methods (Roqib, 2009).

The Iqro 'method was compiled by Ustadz As'ad Human who is domiciled in Yogyakarta. The Book of Iqro 'from the six volumes is added by another volume containing prayers. In every volume there are instructions for learning with the intention of making it easier for everyone who learns and teaches the Qur'an.

The iqro 'method in practice does not require a variety of tools, because it is emphasized in its reading (reading the letters of the Qur'an fluently). Direct reading without spelling. This means that the names of hijaiyah letters are not introduced by active student learning (CBSA) and are more individualized. As for the advantages and disadvantages of the Iqro method 'are:

\section{1).Strengths}

a) Using the CBSA method, so it is not active teachers but students who are demanded to be active.

b) In its application using the private classical (reading together), as well as the way of existence (the higher-volume santri can listen to the reading of his low-bound friends).

c) Communicative means that if students are able to read properly and correctly the teacher can give flattery, attention and respect.

d) If there are students with the same level of learning, may be with the tadarrus system, take turns reading about two lines while the others are listening.

e) The book is easy to get in stores.

2) Weaknesses

a) Tajweed readings are not introduced early. 
b) There is no learning media

c) It is not recommended to use murottal rhythm

\subsection{Learning Method of Reading and Writing Al-Qur'an}

In carrying out the teaching of reading and writing the Qur'an, it is necessary to use appropriate methods in implementing it. It is intended that teaching can be effective and efficient so that students and students will be faster in mastering the material presented. (Syarifuddin, 2008: 81) explains the three teaching methods of Reading the Qur'an as follows:

a. Musyafahah (Tongue Fighting).

The teacher reads first and then the child or student follows. With this method, the teacher can apply how to read letters correctly through his tongue. While the child will be able to see and witness firsthand the practice of letters coming out of the teacher's tongue to mimic, which is called the musyafahah 'tongue-in-mouth'. This method was applied by the Prophet to his friends.

b. 'ArdulQira'ah (Sorongan).

Students read in front of the teacher while the teacher listens. This method is known as the sorongan method or ard ardul qira'ah 'reading deposit'. This method was practiced by Rasulullah SAW together with Angel Gabriel during the Qur'anic reading test in the month of Ramadan.

c. Repeat Word Readings.

The teacher repeats the reading, while the child or student imitates the word words and sentence sentences also repeatedly until they are skilled and correct.

The world of education recognizes that a teaching method always has weaknesses and strengths. The success of a teaching method is largely determined by several things, namely:

a. The ability of teachers as educators.

b. Learners

c. Environment

d. Study material

e. Learning tools

f. The objectives to be achieved

Understanding the Tartili Method is how to read the Qur'an slowly and slowly and pronounce the letters of the makhraj correctly. Reading slowly and precisely can clearly be heard each letter, and its recitation (Aly, Zain, 2009: 2)

While the tartili method is a method of reading the Qur'an used in learning to read the Qur'an and by reading slowly and calmly in accordance with the laws of Tajweed and the signs of waqof. To be able to improve the quality of reading the Qur'an. Because the reading of the Qur'an is not easy and requires a long time to really be able to read the Qur'an and understand the meaning contained in the Qur'an.

\section{Research Methods}

The research method used is qualitative research, data collection is carried out in natural conditions and using data collection methods, namely: interview method, observation method, documentation method. In accordance with the main problems of this study, the types, characteristics, and sources of research carried out, the data collection chosen for further analysis in depth is the method of observation, interviews, and documentation. Sources of data in this study include primary data sources and secondary data sources. Activities in data analysis are: data reduction, data presentation, and drawing conclusions so 
as to produce a product according to the procedures performed by researchers that is the result of students' ability to read and write using the tartili method.

\section{Results and Discussion}

Learning to Read and Write Al-Qur'an Tartili Method is done after the midday prayer in congregation. Starting from the analysis or initial study stage by interview, observation, documentation and analysis of learning planning. Analysis of teacher and student needs for Tartili Teaching material. Then formed the initial product that researchers developed since the beginning of the odd / even semester in the Academic Year 2019/2020.

Researchers conducted interviews with the principal and three teachers recited according to class, namely the homeroom class X (Ten) aliyah, homeroom class XI (eleven) aliyah. XII (Twelve) aliyah.

To find out the results of researchers in the process of planning, implementation and evaluation in Learning to Read the Qur'an Qur'an Tartili Method. Then the planning is done to determine the results of students' abilities, namely a set of plans and arrangements regarding content goals and even learning to achieve certain educational goals. These specific goals include the National education goals, objectives, vision, mission of Madrasas, conformity to the specificities and potentials of the region, education units and students. Therefore, the curriculum that has been determined by the Tartili method also adjusts the situation of the community and the education program with the needs and potential of the region.

Learning to Read and Write Al-Qur'an in MAS Sinar Serdang Perbaungan runs in an orderly manner in accordance with the RPP followed by all students from class X to class XII with enthusiasm in their implementation, this program is not only religious teachers who play a role but all subject teachers also play a role in teaching students, for the division of learning to read and write the Qur'an is adjusted to the level of learning outcomes at home with the teacher to teach it and for students who do not recognize hijaiyah letters then differentiated from other students and in accordance with the ability of students in studying, so every student who is not good enough to recognize hijaiyah letters is not compared to the other students' levels, because the ability to recite the lessons in each child is different, not necessarily students who are higher / more proficient in reading the Koran. The distribution of material for the initial stages of learning is juz 30 (short sura). The teacher gives short surah learning material to students to be written into notebooks by looking at juz'amma / alquran. Then the teacher gives examples of reading in accordance with the Tartil method, after being read then written on the board to know the ability of students to learn to read and write the Qur'an properly and correctly.

Actually, planning is not difficult, in my opinion, it's easy, because there was an RPP arrangement for me the year before, there was an implementation, but not all at the same time implemented this program, only some schools. However, now in July 2020 has been resocialized by the Serdang Bedagai Institution to run the program as a whole in Serdang Bedagai Regency. When teaching the teacher must also adjust the state of students such as the habit of the beginning of learning to read prayer together and provide motivations before starting the material so that they are more directed in the future, after that start reading together with a short surah, then students read forward with the teacher who is assisting them along with writing the letters of the Qur'an on the writing board with the guidance of the accompanying teacher. Guiding students must be more patient and diligent, so that we get satisfying results on our students. 
Each level in Mas Sinar Serdang Perbaungan adjusts to the level of the class/group, starting from the first volume / juz to the end as well as juz 30 (juz'amma). For the beginning of student learning beginners are still learners of hijaiyah letters first, so students can continue further learning, after students are able it will be followed by reading short surahs, for students who have been able to stage the first and second stages then the student has the right to rise to the next level, namely reading juz first according to the division of reading until the end of juz. In the application of this learning students must know the kinds of societies, continued letters and readings with recitation and reading al-qur'an waqof sign. For learning to write Arabic letters al-Qur'an students write them in front of the blackboard according to the instructions of the teacher until the end of the learning process.

In the next learning stage, Marhala Ula, students who have graduated from the initial learning stage go up to the next lesson, learning to read the Qur'an starting from juz 1-10 after graduation, then going up to the next level Marhala Wustho, starting juz 11-20. When learning takes place students must have the Qur'an one by one, for female students who cannot participate in learning due to the absence (Menstruation) get relief to read their readings when it will come after the hindrance period has finished.

The initial learning activity aims to prepare the condition of students every time they receive material. Readiness includes attention, physical mental and social emotional in order to focus on learning activities to be carried out. From the observations of researchers on the planning of the Read and Write Al-Qur'an with the first Tartil method the teacher greets students, absent students' attendance, the teacher gives motivation to students, the teacher recalls the previous material and is read together (Muroja'ah).

This activity is habituated as is done in other learning activities. Although at the beginning of learning the teacher does not convey the learning objectives students already know because of each meeting conducted the same as before so students are familiar and know it. The preparation required by the teacher in teaching is that the lesson plan understands and learns the lesson plan that has become a curriculum guide in the Tartil method.

The process of implementing learning is one of the success factors of teachers in implementing learning, teachers are required to be professional in understanding student conditions and adjusting sentences that are easily understood by students in this learning.

Likewise the method used is also an important role in the teaching and learning process. This madrasa chooses the Tartil method because it is easier, the teacher does not have to have a shahadah to teach using the Tartil method, in addition there is also a Tartil method training for teachers, but the training time is not binding, so it is more flexible because the teacher can learn while teaching does not confiscate teacher time.

In the implementation of the initial activity after the teacher knows the condition of students in class / absence, students together read short letters and daily prayers as a form of memorization, after that together students begin to open books to start the lesson that has previously been learned or Muroja ' Ah. Then on the page specified in the Koran the teacher reads the students listening, as long as the teacher reads students mark the parts of the verse that should stop or read on and listen to the signs of recitation, in this section the teacher repeats twice while the teacher explain it.

Furthermore students mimicked reading together. Then the students read together without imitating and the teacher listens to the students 'reading and corrects the students' reading, the reading using the Tartil method using Tartil's own song. When reading a loud voice is carried out so that it is compact and vibrant. Then students come forward to the class reading one by one in front of the teacher. As the students progress one by one the other 
students are instructed to write their own books, which are written short written suras as directed by the teacher.

Implementation is in accordance with the lesson plan but it is more simple to follow the rules of the hour, divided into sometime between the beginning of opening, giving material, individual advanced drill, finally memorizing as supporting material and can be placed at the beginning of learning or the end of learning.

In the implementation process at each class or every level has a difference in teaching adjusting the conditions of students, but the implementation process still follows the rules of RPP, if in class XII is a class included in the high category will be different from the condition of low grade students namely class XI (Two) Aliyah. Researchers see here the teacher must be more patient and more active in conditioning students, but the implementation is the same as what researchers have explained in the learning process in the classroom.

In this class there are mixed children who are fluent and those who have not, in Tartil's guidelines must be classical and those children are bored because they cannot read, each child is different so I emphasize more after reading that writing and my goal emphasizes more writing so that students read while writing silently the aim is to be able to read and write, even though the implementation process remains the same as the lesson plan.

In class X (ten) Marhala Ula students and teachers enter the class, then read prayers together, finished praying the teacher motivates to give encouragement, after that the beginning of the teacher's material writes the recitation material students write it. After writing the teacher read al-quran, the students listened and marked the reading of the letter the teacher read, the teacher read marked with waqof in the Tartil method. Then the students read together and the teacher gives questions about recitation of recitation, while recollecting recitation material. The final activity of students one by one reading forward is listened to by the teacher after all have finished praying together and go home.

Writing and memorizing activities such as short surahs and daily prayers are also carried out in the classroom to be the target of students' success in learning. The situation of each class must be different with the conditions and learning styles of each individual student, sometimes creating obstacles and difficulties faced by the teacher and also the students themselves. The problem is that students who are behind or do not understand will be left behind by other friends, the teacher teaches themselves so you don't get left behind by other friends. And if there is a child who does not take up the volume then the student still has to repeat it until he rises to the next volume and so on, the end of the desired target of the madrasa is to graduate the student is able to memorize the Qur'an and be able to memorize the short surah (juz 30) namely surah Adh -dhuha-An-Nass, but the madrasa does not just let the predetermined target be realized and students who are left behind are treated in order drill classes.

The assessment system in the base class at each meeting is individual, after reading together the teacher orders each student to come forward facing the reading teacher and the teacher listens to it accompanied by assessing on the student achievement card or the connecting value between parents and the school so that parents know the progress the ability of their children in school. Besides that, some students waited in the queue to setor to read forwards while others wrote, namely to write memorized short surahs and then write them in front of the blackboard one by one. Writing activities are done so that students do not make noise/rowdy with each other so that the class is controlled, while waiting and practicing so that the writing becomes good after that writing is assessed by the teacher, and so on. These materials affect other subjects as Islamic Education subjects and as an ability for each individual. 
The standard of each child, the teacher makes a standard assessment of competence with a minimum increase in value of 70 , as well as assessments every day, there are reading criteria for each student according to the recitation. The assessment done at the end of the lesson is done every day or every meeting. Once a month, a maximum of once every three months there is an assessment from the school supervisors who come from the management board of the BTQ program to check that the activity is running smoothly and to do tests in each class to find out the ability of students who are unable to learn.

For students who are not fluent in reading and writing can not be increased or transferred to the next material. So students stick to the previous material until students are able to read and write well according to the recitation. For students who are left behind the material while the student has reached, then a drill is conducted for the student, so they can graduate to the next level according to the target and objectives of the madrasa.

Assessments conducted at the madrasa are assessments of memorization of short surahs, daily prayers, readings and also student writing. Whereas the evaluation criteria from the center, namely the supervisor of the Madrasah Kamenag Serdang Bedagai Perbaungan, are only reading, but writing supports students to be able to test. Detailed assessment when reading tests are recitation, makhrojul letters, and fluency, if the increase in volume is accompanied by rote also because rote as a support to achieve the goals of the madrasa.

\section{Conclusion}

The planning for reading and reading al-quran with the Tartil method is based on the lesson plan that the teacher has designed to regulate the conditions of students in the class while the preparation required is self-supporting material for memorizing short letters. Daily prayer and Arabic writing to improve the quality of students' abilities.

The implementation of learning to read and write al-quran with the tartil method begins with reciting daily prayers or short letters together, then entering the teacher's material to read and explain, while students listen to the book / al-quran. Then the students read together several times after that writing by transferring the writing in the quran to the notebook after writing is assessed by the teacher.

Evaluation of reading and writing learning al-quran with tartil method, daily assessment is carried out at each student learning meeting tested one by one in the future the teacher. Evaluation of volume increase is carried out by the madrasa and there is a team of teachers to carry out tests

\section{References}

Budianti, R. (2020). Implementation of Tikrar Methods in Memorizing Al-Qur'an in

Tahfidzul Qur'an Foundation Al-Fawwaz Medan. Budapest International Research and Critics in Linguistics and Education (BirLE) Journal. P. 974-980.

Chandra; Fransisca. (2009). "Peran Partisipasi Kegiatan di Alam Masa anak, Pendidikan dan Jenis Kelamin sebagai Moderasi Terhadap Perilaku Ramah Lingkungan”. Disertasi S3. Program Magister Psikologi Fakultas Psikologi. Universitas Gajah Mada Yogyakarta.

Dinas Pendidikan dan Kebudayaan. (2007). Kurikulum Daerah (Semarang)

Hadari Nawawi H. (2012) Bimibingan Pribadi Konseling Pendidikan sebagaimana dikutip Abdul Majid, Perencanaan Pembelajaran Pengembangan Standart Kompetensi Guru (Bandung: PT Remaja Rosdakarya.

Majid Abdul. (2013). Strategi Pembelajaran, (Bandung: Remaja Rosdakarya) 
Ma'mun Muhammad Aman, Jurnal Pendidikan Islam. (2018). Kajian Pembelajaran Baca Tulis Al-Qur'an, Vol. 4, No. 1, Maret.

Moedjiono (ed). (2012) Proses Belajar Mengajar (Bandung:Remaja Rosda Karya)

Muhaimin. (1993). Pemikiran Pendidikan Islam: Kajian Filosofis dan Kerangka Dasar Operasionalisasinya (Cet. I; Mizan)

Munandar Utami. (2011). Pengembangan Kreativitas Anak Berbakat, Sebagaimana dikutip oleh Suryono dan Hariyanto, Belajar dan Pembelajaran (Bandung: Remaja Rosdakarya)

Srijatun. (2017). Jurnal Pendidikan Islam, Implementasi Pembelajaran Baca Tulis Al-Qur'an Dengan Metode Iqro Pada Anak Usia Dini RA Perwanida Slawi Kabupaten Tegal, Vol. 11, No. 1, ISSN 1979-1739 (P); ISSN 2502-8057 (E).

Syarifuddin Ahmad. (2008). Mendidik Anak Membaca, Menulis dan Mencintai Al-Qur'an (Bandung: Remaja Rosdakarya)

Zain Abu Ubaidillah, Aly Abu Sabiq, Kaidah-kaidah Membaca Al-Qur'an dengan Tartil, (Jakarta : Al-Qamar Media, 